Conditionally Accepted 



\title{
Conditionally Accepted
}

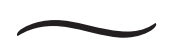

Christians' Perspectives on Sexuality and Gay and Lesbian Civil Rights

\author{
BAKER A. ROGERS
}

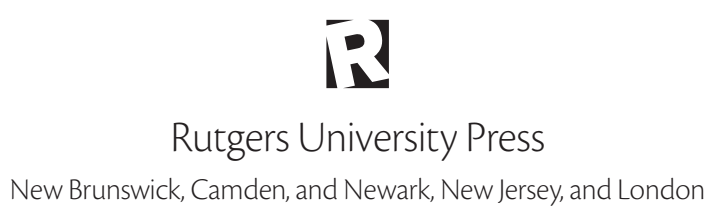


Library of Congress Cataloging-in-Publication Data

Names: Rogers, Baker A., author.

Title: Conditionally accepted : Christians' perspectives on sexuality and gay and lesbian civil rights / Baker A. Rogers.

Description: New Brunswick : Rutgers University Press, 2019. | Includes bibliographical references and index.

Identifiers: LCCN 20190I0256 | ISBN 97819788050I9 (hardback) | ISBN 9781978805002 (pbk.)

Subjects: LCSH: Sex—Religious aspects—Christianity. | Homosexuality—Religious aspects—Christianity. | Sexual rights.

Classification: LCC BT708 .R564 2019 | DDC 233/.5-dc23

$\mathrm{LC}$ record available at https://1ccn.loc.gov/2019010256

A British Cataloging-in-Publication record for this book is available from the British Library.

Copyright (C) 2020 by Baker A. Rogers

All rights reserved

No part of this book may be reproduced or utilized in any form or by any means, electronic or mechanical, or by any information storage and retrieval system, without written permission from the publisher. Please contact Rutgers University Press, ro6 Somerset Street, New Brunswick, N.J. o89or. The only exception to this prohibition is "fair use" as defined by U.S. copyright law.

( The paper used in this publication meets the requirements of the American National Standard for Information Sciences-Permanence of Paper for Printed Library Materials, ANSI Z39.48-I992.

www.rutgersuniversitypress.org

Manufactured in the United States of America 
I dedicate this work to all lesbian, gay, bisexual, transgender, and otherwise queer individuals who have struggled to accept themselves due to religious teachings and to all the religious leaders who stand for equality and love. 
